\title{
PENINGKATAN PRESTASI BELAJAR KORESPONDENSI MELALUI MODEL PEMBELAJARAN TEAM-ASSISTED INDIVIDUALIZATION
}

\author{
Siti Khoriah Nurhasanah \\ SMK Negeri 1 Sragen \\ Email: sk.nurhasanah19@gmail.com
}

\begin{abstract}
Abstrak
Tujuan penelitian ini adalah untuk meningkatkan prestasi belajar korespondensi melalui penerapan model pembelajaran kooperatif Team Assisted Individualization (TAI) siswa Kelas X OTKP 3 SMK Negeri 1 Sragen semester gasal tahun pelajaran 2017/2018. Penelitian ini berbentuk penelitian tindakan kelas. Subyek penelitian ini adalah siswa kelas X OTKP 3 SMK Negeri 1 Sragen yang berjumlah 36 orang. Hasil penelitian yang telah dilakukan adalah ada peningkatan prestasi belajar korespondensi siswa dari 21 siswa (58\%) yang tuntas pada pra siklus menjadi 27 siswa (75\%) yang tuntas pada siklus I dan meningkat menjadi 35 siswa $(97 \%)$ yang mencapai batas ketuntasan belajar. Nilai rata-rata prestasi belajar Korespondensi meningkat dari 69,58 pada pra siklus menjadi 75,69 (meningkat 9\%) pada siklus I dan menjadi 82,64 (meningkat 19\%) pada siklus II. Berdasarkan hasil penelitian yang dilakukan dapat disimpulkan bahwa terjadi peningkatan prestasi belajar Korespondensi siswa kelas X OTKP 3 SMK Negeri 1 Sragen melalui penerapan model pembelajaran Team Assisted Individualization (TAI).
\end{abstract}

Kata kunci: Team Assisted Individualization, Prestasi belajar.

\section{INCREASING CORRESPONDENCE LEARNING ACHIEVEMENTS THROUGH TEAM ASSISTED INDIVIDUALIZATION MODEL}

\author{
Siti Khoriah Nurhasanah \\ SMK Negeri 1 Sragen \\ Email: sk.nurhasanah19@gmail.com
}

\begin{abstract}
Abstrack
The purpose of this study is to improve the learning achievement of correspondence through the implementation of cooperative learning model Team Assisted Individualization (TAI) students Class $X$ OTKP 3 SMK Negeri 1 Sragen semester gasal year 2017/2018. This research is in the form of classroom action research. The subjects of this study were students of class X OTKP 3 SMK Negeri 1 Sragen which amounted to 36 people. The result of this research is the improvement of students' correspondence achievement from 21 students (58\%) completed in pre cycle to 27 students (75\%) completed in the first cycle and increased to 35 students (97\%) who reach the learning threshold. The average value of learning achievement Correspondence increased from 69.58 in pre cycle to 75.69 (9\% increase) in cycle I and became 82.64 (19\% increase) in cycle II. Based on the results of research conducted it can be concluded that there is an increase in learning achievement Correspondence students of class X OTKP 3 SMK Negeri 1 Sragen through the implementation of Team Assisted Individualization (TAI) learning model.
\end{abstract}

Keywords: Team Assisted Individualization, Achievement learning 


\section{PENDAHULUAN}

Pendidikan merupakan sebuah proses, oleh karena itu untuk menciptakan lulusan yang berkualitas dan memiliki kapabilitas yang tinggi perlu melalui proses pembelajaran yang berkualitas. Dalam proses belajar mengajar guru memegang peranan penting dalam pencapaian tujuan. Tugas seorang guru adalah mendidik dan mengajar siswa hingga berhasil dalam belajar dan mampu menghadapi tantangan hidup. Jadi, guru berperan dalam upaya meningkatkan prestasi belajar siswa. Salah satu upaya yang dilakukan untuk meningkatkan kualitas pendidikan adalah dengan cara penerapan model pembelajaran yang kreatif dan inovatif dalam kegiatan pembelajaran.

Berdasarkan dokumentasi nilai mata pelajaran korespondensi menunjukkan bahwa hasil belajar mata pelajaran tersebut pada siswa kelas X OTKP 3 SMK Negeri 1 Sragen masih banyak yang mendapat nilai di bawah kriteria ketuntasan minimal yaitu 70. Survei awal menunjukkan masih terdapat 15 siswa (42\%) yang memperoleh nilai di bawah kriteria ketuntasan minimal. Tingkat penguasaan materi korespondensi siswa masih relatif rendah. Siswa tidak terlalu antusias dan kurang aktif dalam mata pelajaran korespondensi karena siswa cenderung tidak menggunakan kesempatan untuk bertanya tentang kesulitan yang mereka hadapi.

Dalam penelitian ini alternatif penyelesaian yang akan diterapkan adalah penggunaan model pembelajaran Team Assisted Individualization (TAI). Dalam pembelajaran ini didapatkan adanya proses kebersamaan dalam menyelesaikan suatu permasalahan. Model pembelajaran kooperatif TAI dapat diterjemahkan sebagai suatu model yang dirancang khusus untuk memecahkan masalah-masalah yang sama dengan menggabungkan pembelajaran kooperatif dan pembelajaran individual. Penggunaan model pembelajaran kooperatif TAI akan meningkatkan kemampuan akademik, yaitu prestasi belajar siswa dan motivasi belajar siswa. Hal ini dikarenakan apabila siswa diajar secara kooperatif akan terjadi kerjasama di dalam kelompoknya, maka siswa akan lebih senang dan menyukai materi pelajaran yang diberikan. Ada tiga tipe siswa yang berkaitan dengan belajar, siswa yang berkemampuan awal tinggi, siswa yang berkemampuan awal sedang dan siswa yang berkemampuan awal rendah. Siswa yang mempunyai kemampuan awal tinggi akan lebih mudah dalam memahami materi pelajaran yang diajarkan. Begitu juga sebaliknya, siswa yang memiliki kemampuan awal rendah akan mengalami kesulitan dalam memahami pelajaran. Harapannya setelah penerapan model pembelajaran ini siswa yang telah mencapai KKM sudah lebih dari $80 \%$ dari jumlah siswa atau sebanyak 29 orang. 
Tujuan dari penelitian ini adalah untuk meningkatkan kualitas pembelajaran dan prestasi belajar korespondensi melalui penerapan model pembelajaran TeamAssisted Individualization (TAI).

Salah satu tugas guru adalah "mengevalusai tingkat keberhasilan rencana pelaksanaan kegiatan belajar-mengajar. Perubahan yang dikehendaki adalah perubahan dalam bidang pengetahuan, perasaan atau sikap dan perbuatan" Surjadi (1989: 177). Menurut Sudjana (2010: 3) "hasil belajar pada hakikatnya adalah perubahan tingkah laku, sebagai hasil belajar mencakup bidang kognitif, afektif, dan psikomotoris“. Untuk mencapai tujuan dari pelaksanaan kegiatan pembelajaran seorang guru perlu menyiapkan strategi yang di dalamnya termasuk metode dan model mengajar yang akan dilakukan.

Berkaitan dengan karakteristik materi dan siswa yang diajar serta kurikulum yang berlaku saat ini, sudah saatnya guru menerapkan model pembelajaran kooperatif. Menurut Slavin yang dikutip Isjoni (2012: 22), “in cooperative learning methods, students work together in four member teams to master material initially presented by the teacher". Dari uraian tersebut dapat dikemukakan bahwa pembelajaran kooperatif adalah suatu model pembelajaran dimana sistem belajar dan bekerja dalam kelompok-kelompok kecil yang berjumlah 4-6 siswa secara kolaboratif sehingga dapat merangsang siswa lebih bergairah dalam belajar.

Pembelajaran kooperatif ini bukan bermaksud untuk menggantikan pendekatan kompetitif (persaingan). Nuansa kompetitif dalam kelas akan sangat baik bila diterapkan secara sehat. Pendekatan kooperatif ini adalah sebagai alternatif pilihan dalam mengisi kelemahan kompetisi, yakni hanya sebagian siswa saja yang akan bertambah pintar, sementara yang lainnya semakin tidak tahu. Tidak sedikit siswa yang kurang dalam pengetahuannya merasa malu bila kekurangannya di-expose. Kadang-kadang motivasi persaingan akan menjadi kurang sehat bila para murid saling menginginkan murid lainnya tidak mampu. Sikap mental inilah yang dirasa perlu untuk mengalami perbaikan.

Model pembelajaran yang digunakan dalam penelitian ini adalah model pembelajaran Team Assisted Individualization (TAI). Terjemahan bebas dari model ini adalah Bantuan Individual dalam Kelompok dengan karakteristik bahwa tanggung jawab belajar adalah pada siswa. Oleh karena itu siswa harus membangun pengetahuan tidak menerima bentuk jadi dari guru. Pola komunikasi guru-siswa adalah negosiasi dan bukan imposisi-intruksi. Urutan langkah pembelajaran model Team Assisted Individualization (TAI) dari adalah : (1) buat kelompok heterogen dan berikan 
bahan ajar berupa modul, (2) siswa belajar kelompok dengan dibantu siswa yang ahli atau terampil dalam anggota kelompok secara individual, saling tukar jawaban, saling berbagi sehingga terjadi diskusi, (3) penghargaan kelompok dan refleksi serta tes formatif.

Tahap-tahap pembelajaran Team Assisted Individualization (TAI) dalam pembelajaran korespondensi pada penelitian ini adalah sebagai berikut: 1) guru menentukan suatu pokok bahasan yang akan disajikan kepada siswa dengan mengadopsi model pembelajaran Team Assisted Individualization. 2) Guru menjelaskan kepada seluruh siswa tentang akan diterapkanya model pembelajaran TAI, sebagai suatu variasi model pembelajaran dan guru menjelaskan kepada siswa tentang pola kerjasama antara siswa dalam satu kelompok. 3) Guru menyiapkan materi bahan ajar yang harus dikerjakan kelompok, guru juga dapat memanfaatkan LKS yang dimiliki oleh siswa. 4) Guru memberikan pra siklus tentang materi yang akan diajarkan. 5) Guru menjelaskan materi baru secara singkat. 6) Guru membentuk kelompok kecil dengan anggota 6 orang siswa pada setiap kelompoknya. Kelompok dibuat heterogen tingkat kepandaiannya dengan memperhatikan keharmonisan kerja kelompok. 7) Tiap ketua kelompok diberi penjelasan khusus dari guru. 8) Guru menugasi kelompok dengan bahan yang sudah disiapkan. 9)
Ketua kelompok melaporkan keberhasilan atau hambatan yang dilalami anggota kelompoknya kepada guru. Jika diperlukan guru melakukan bantuan secara individual kepada siswa. 10) Ketua kelompok harus dapat menetapkan bahwa setiap anggota telah memahami materi bahan ajar yang diberikan oleh guru, dan siap untuk diberi tes oleh guru. 11) Guru memberikan tes dan guru harus mengumumkan hasilnya dan menetapkan kelompok terbaik sampai kelompok yang kurang berhasil (jika ada). 12) Menjelang akhir waktu, guru memberikan latihan pendalaman secara klasikal dengan menekankan strategi pemecahan masalah. Serta, 13) Guru dapat memberikan tes formatif sesuai dengan kompetensi yang ditentukan.

\section{METODODE PENELITIAN}

Penelitian ini dilaksanakan dengan pendekatan Penelitian Tindakan Kelas (PTK). PTK dilaksanakan dengan strategi siklus yang berangkat dari identifikasi masalah yang dihadapi oleh guru, penyusunan rencana tindakan, pelaksanaan tindakan, observasi tindakan, dan refleksi. Rangkaian kegiatan berurutan mulai dari perencanaan tindakan sampai dengan refleksi disebut satu siklus penelitian. Jika dalam setiap refleksi ditemukan masalah yang dihadapi guru, baik masalah baru maupun masalah lama yang dianggap mengganggu tercapainya PTK, maka guru dapat mengidentifikasi, menganalisis, dan 
merumuskan masalah tersebut. Selanjutnya, guru dapat melakukan penelitian lebih lanjut pada siklus berikutnya, yang dimulai dari penyusunan rencana tindakan sampai dengan refleksi. Namun, jika refleksi pada siklus tertentu tidak terjadi kendala dan tujuan PTK telah terselesaikan/tercapainya, maka penelitian tidak perlu dilanjutkan ke siklus kedua.

Subyek penelitian dalam penelitian ini adalah siswa kelas $\mathrm{X}$ OTKP 3 tahun pelajaran 2017/2018 dengan jumlah siswa 36 anak.

Teknik pengumpulan data yang digunakan dalam penelitian ini meliputi: 1) Observasi, digunakan untuk mengamati pelaksanaan dan perkembangan pembelajaran yang dilakukan oleh guru dan siswa. Pengamatan dilakukan sebelum, selama, dan sesudah siklus penelitian berlangsung. 2) Tes, digunakan untuk mengetahui perkembangan atau keberhasilan pelaksanaan tindakan. Adapun bentuk tes yang diberikan kepada siswa, yakni tes yang berupa tes tertulis. Serta 3) Dokumentasi, digunakan untuk mengetahui Berdasarkan hasil pelaksanaan tindakan pada siklus I dan II dapat dinyatakan bahwa terjadi peningkatan prestasi belajar korespondensi dengan menggunakan model pembelajaran kooperatif Team-Assisted Individualization (TAI) dari siklus satu ke siklus berikutnya. Hasil tersebut telah menunjukan bahwa setelah digunakannya model pembelajaran data peserta didik, nilai-nilai pra siklus sampai dengan siklus II dan foto-foto pelaksanaan tindakan kelas sampai dengan pelaksanaan seminar.

\section{HASIL DAN PEMBAHASAN}

Berdasarkan data penelitian diperoleh nilai tes awal pra siklus, hanya 21 siswa yang tuntas yaitu nilai memenuhi KKM dengan persetase $58 \%$ dan sisanya 15 siswa atau $42 \%$ masih belum tuntas. Kemudian ketuntasan belajar yang tercapai pada siklus I adalah sebanyak 27 siswa dengan persentase sebesar $75 \%$ telah memenuhi KKM dan 9 siswa atau 25\% yang belum memenuhi KKM. Pada siklus I sudah terlihat peningkatan persentase meskipun belum mencapai target tujuan yang ditetapkan sehingga perlu melakukan tindakan siklus II . Kemudian untuk siklus II, ketuntasan prestasi belajar yang tercapai sebanyak 35 siswa dengan persentase sebesar $97 \%$ dan hanya 1 siswa yang dinyatakan belum tuntas yaitu sekitar $3 \%$. Untuk lebih jelasnya dapat dilihat pada tabel berikut ini.

\section{kooperatif Team-Assisted Individualization} (TAI) membawa perubahan yang positif dalam pembelajaran korespondensi. Perubahan yang terlihat adalah: 1) Siswa menjadi lebih antusias dalam mengikuti pembelajaran korespondensi, 2) Siswa menjadi lebih bersemangat dan aktif pada saat diskusi kelompok, serta 3) Siswa menjadi lebih mudah memahami materi 
pembelajaran karena guru dan teman-

kesulitan belajar yang dialami.

temannya mau membantu mengatasi

Tabel 1. Rangkuman Ketuntasan Prestasi Belajar Pra Siklus, Siklus I dan Siklus II

\begin{tabular}{lcccccc}
\hline \multirow{2}{*}{ Kategori } & \multicolumn{2}{c}{ Pra Siklus } & \multicolumn{2}{c}{ Siklus I } & \multicolumn{2}{c}{ Siklus II } \\
\cline { 2 - 7 } & $\begin{array}{c}\text { Jumlah } \\
\text { Siswa }\end{array}$ & Persentase & $\begin{array}{c}\text { Jumlah } \\
\text { Siswa }\end{array}$ & Persentase & $\begin{array}{c}\text { Jumlah } \\
\text { Siswa }\end{array}$ & Persentase \\
\hline Tuntas & 21 & 58 & 27 & 75 & 35 & 97 \\
Tidak Tuntas & 15 & 42 & 9 & 25 & 1 & 3 \\
Jumlah & 36 & 100 & 36 & 100 & 36 & 100 \\
\hline
\end{tabular}

Sumber : (Sumber : Data Hasil Penelitian)

Berdasrkan hasil pengamatan pelaksanaan siklus II terlihat bahwa masalah yang dihadapi pada pembelajaran korespondensi di kelas X OTKP 3 sudah dapat teratasi dengan penerapan model pembelajaran kooperatif Team-Assisted Individualization.

\section{KESIMPULAN DAN SARAN}

Berdasarkan hipotesis tindakan yang telah dikemukakan dan tindakan penelitian yang telah dilakukan, diperoleh simpulan bahwa terdapat peningkatan prestasi belajar korespondensi dengan menerapkan model pembelajaran kooperatif TeamAssisted Individualization (TAI) pada siswa kelas X OTKP 3 SMK Negeri 1 Sragen semester gasal tahun pelajaran 2017/2018.

Berkaitan dengan kesimpulan di atas, maka ada beberapa saran yang dapat dilakukan sebagai berikut. 1) Kepala Sekolah, hendaknya selalu mendorong guru untuk berani mengembangkan dan menerapkan model pembelajaran yang lebih aktif, inovatif, kreatif dan menyenangkan siswa aga mereka bersemangat mengikuti kegiatan pembelajaran. Kepala sekolah juga perlu mengusahakan tercukupinya sarana dan prasarana pendukung kegiatan pembelajaran untuk meningkatkan kualitas pembelajaran. 2) Bagi Guru, hendaknya lebih intensif mengembangkan model pembelajaran yang kreatif dan menyenangkan sesuai dengan karakteristik materi dan siswa yang diampunya, serta mau meluangkan waktu untuk pendekatan individual kepada siswa yang bermasalah dengan belajarnya agar segera dapat mengatasinya dan mampu meningkatkan prestasi belajar mereka. 3) Bagi Siswa, hendaknya mampu memanfaatkan kegiatan diskusi kelompok untuk membentuk karakter yang bertanggung jawab, toleransi dan kerja keras, serta mampu 
memanfaatkan pembelajaran yang

kooperatif ini untuk meningkatkan pemahamannya pada materi karena kegiatan pembelajaran berjalan dengan menyenangkan.

\section{DAFTAR PUSTAKA}

Agus Suprijono. (2009). Cooperative Learning Teori dan Aplikasi Paikem. Surabaya: Pustaka Pelajar.

Anita. Lie. (2002). Mempraktikkan Coopertive Learning di Ruang-Ruang Kelas. Jakarta: Gramedia.

Arikunto, Suharsimi. (2011). Penelitian Tindakan.Yogyakarta: Aditya Media

Arikunto, S., Suhardjono, Supardi. (2006). Penelitian Tindakan Kelas. Jakarta: PT Bumi Aksara.

Arnie Fajar, dkk. (2005). Portofolio dalam Pembelajaran IPS. Bandung: PT Remaja Rosdakarya.

Asmani, Jamal Ma'mur. (2013). 7 Tips Aplikasi PAIKEM. Jogyakarta: Diva Press.

Aunurrahman. (2012). Belajar dan Pembelajaran. Bandung: Penerbit Alfabeta.

Asri Budiningsih. (2005). Belajar dan Pembelajaran. Jakarta: PT Asdi Mahasatya.

Daryanto dan Mulyo R. (2012). Model Pembelajaran Inovatif. Yogyakarta: Gava Media.

Dimyati dan Mudjiono. (2009). Belajar dan Pembelajaran. Jakarta: Rineka Cipta.

Indra Bastian. (2006). Akuntansi Pendidikan. Yogyakarta: Erlangga.

Hamdani. (2011). Strategi Belajar Mengajar. Bandung: CV Pustaka Setia.
Kalhani Kasholah. (2001). Penelitian Tindakan Kelas Untuk Guru. Malang: Universitas Negeri Malang.

Moleong, Lexy J. (2010). Metodologi Penelitian Kualitatif. Bandung: PT Remaja Rosdakarya.

Mulyasa. (2007). Standar Kompetensi dan Sertifikasi Guru. Bandung: PT Remaja Rosdakarya.

Muhibbin Syah. (2005). Psikologi Pendidikan Dengan Pendekatan. Bandung: PT Remaja Rosdakarya.

Mulyani Sumantri dan Johar Permana. (2001). Strategi Belajar Mengajar. Bandung: PT Remaja Rosdakarya.

Nana Sudjana. (2008). Penilaian Hasil Proses Belajar Mengajar. Bandung: PT Remaja Rosdakarya.

Oemar Hamalik. (2003). Kurikulum dan Pembelajaran. Jakarta : Bumi Aksara.

Permendikbud No. 70 Tahun 2013 tentang Kerangka Dasar dan Struktur Kurikulum Sekolah Menengah Kejuruan/ Madrasah Aliyah Kejuruan.

Permendikbud No. 81A Lapiran IV tahun 2013 tentang Pedoman Umum Pembelajaran.

Purwanto. (2013). Evaluasi Hasil Belajar. Yogyakarta: Pustaka Pelajar.

Purwanto, Ngalim. (2004). Prinsip-Prinsip dan Teknik Evaluasi Pengajaran. Bandung: PT Remaja Rosdakarya.

Rini Budiharti. (2002). Strategi Belajar Mengajar. Surakarta: UNS Press.

Sardiman AM. (2007). Interaksi dan Motivasi Belajar Mengajar. Jakarta: PT Raja Grafindo Persada.

Slameto. (2003). Belajar dan Faktor-Faktor yang Mempengaruhinya. Jakarta: PT Rineka Cipta.

Sudjana, Nana. (2005). Penilaian Hasil Proses Belajar Mengajar. Bandung: PT Remaja Rosdakarya. 
Sukmadinata, Nana Syaodih. (2004). Landasan Psikologi Proses Pendidikan. Bandung: PT Remaja Rosdakarya.

Undang-Undang Republik Indonesia Tentang Sistem Pendidikan Nasional (Sisdiknas) Tahun 2003.

Uno, Hamzah B dan Nurdin Mohamad. (2011). Belajar dengan Pendekatan PAIKEM. Jakarta: PT Bumi Aksara.

Wilis, Ratna D. (2011). Teori-Teori Belajar dan Pembelajaran. Bandung: Erlangga. 